Article

\title{
Sustainability of Land Use Promoted by Construction-to-Ecological Land Conversion: A Case Study of Shenzhen City, China
}

\author{
Yunfei Peng ${ }^{1}$, Jing Qian ${ }^{5}$, Fu Ren ${ }^{1,2,3}$, Wenhui Zhang ${ }^{6}$ and Qingyun Du ${ }^{1,2,3,4, *}$ \\ 1 School of Resource and Environmental Science, Wuhan University, 129 Luoyu Road, Wuhan 430079, China; \\ pengyf@whu.edu.cn (Y.P.); renfu@whu.edu.cn (F.R.) \\ 2 Key Laboratory of GIS, Ministry of Education, Wuhan University, 129 Luoyu Road, Wuhan 430079, China \\ 3 Key Laboratory of Digital Mapping and Land Information Application Engineering, \\ National Administration of Surveying, Mapping and Geo-information, Wuhan University, 129 Luoyu Road, \\ Wuhan 430079, China \\ 4 Collaborative Innovation Center of Geospatial Technology, Wuhan University, 129 Luoyu Road, \\ Wuhan 430079, China \\ 5 Shenzhen Urban Planning and Land Resource Research Center, 8009 Hongli Road, Shenzhen 518040, China; \\ qianjing@whu.edu.cn \\ 6 Shenzhen Institute of Building Research, Co., Ltd., No. 29, 3 Meiao Road, Shenzhen 518049, China; \\ zhangwenhui@pku.edu.cn \\ * Correspondence: qydu@whu.edu.cn; Tel.: +86-27-8766-4557; Fax: +86-27-6877-8893
}

Academic Editor: Tan Yigitcanlar

Received: 6 June 2016; Accepted: 11 July 2016; Published: 14 July 2016

\begin{abstract}
Rapid urbanization and rapid urban growth present great challenges to the sustainable utilization of land resources. This paper discusses the on-going process of construction-to-ecological land conversion (CELC) in terms of three aspects: land use, environmental effects, and system responses. CELC is compared to other current land conversion strategies in China. Taking Shenzhen City as an example, this paper introduces five areas in which CELC has been implemented since 2009, including basic farmland protection zones, mining areas, ecological corridors, inefficient industrial zones, and urban villages. This paper argues that Shenzhen's CELC model can improve the ecological environment, control urban sprawl, and promote sustainable land use and, thus, serve as an example for other cities in China.
\end{abstract}

Keywords: land conversion; land use; ecology; sustainability; urban expansion

\section{Introduction}

Since the 1978 economic reforms, China has entered a phase of rapid urbanization [1]. The attendant urban sprawl has brought a series of problems to sustainable urban development, such as food insecurity [2], farmers losing land [3], traffic congestion [4], air pollution [5], and ecological insecurity [6]. With China's urbanization level exceeding 56\% in 2015, China is in a critical period of rapid urban development [7]. Faced with the challenges of changing economic growth modes and economic structural adjustment, the past pattern of extensive expansion of construction land has been difficult to continue [8]. Therefore, developing forward-looking policies to control urban sprawl has become a main concern for academia, government agencies and the public [9-11].

In Western developed countries, the expansion of urban areas received attention as early as the 1920 s and had aroused public concern by the end of the 1960s [12,13]. There are different opinions about the causes of urban expansion. Economists argue that economic factors are the primary drivers of land use change, but market failures are common because of imperfect competition in the land 
market and land use externalities, such as the public goods attributes of land [14]. Some scholars believe that the influences of social groups on land use change need to be explained with reference to laws, regulations, and policies [15]. There are many approaches to the practice of controlling urban land expansion, including growth management [16], "smart growth" [17], New Urbanism [18], ecological networks, and greenways [19] in the USA; greenbelt policy in the UK [20]; the Compact City Policy in the Netherlands and other developed countries [21]; and land readjustment in Japan [22]. According to the tenets of growth management, city planning, regulations, and the financial power of the state and local governments should be combined to influence urban growth and development [23]. In "smart growth", land use and transportation are made more efficient through the establishment of development principles and planning efforts [24]. New Urbanism focuses on urban community development at a very local level and aims to create compact neighbourhoods with adequate walking spaces through mixed land use [25]. Ecological networks and greenways, combined with green open space protection policies, suppress urban sprawl and protect ecological spaces by optimizing the layout of the urban ecological landscape [26]. At the beginning of the 20th century, Great Britain implemented greenbelt policies and other laws to control urban land exploitation. Greenbelts were set up between urban and rural areas to fully realize their function of separating urban spaces. Since the policies were secured by laws and won the support of the public, they effectively restrained urban sprawl [27]. In 1988, the Netherlands proposed their Compact City policy [28], which was later recognized by the European Community Committee as "a solution to residential and environmental problems" and attracted international attention [29]. Having been adopted in the Great Britain, France, Germany, Italy, and other countries, it was also introduced as a target in the "Melbourne 2030" Plan in 2002 by Australia to add vitality to downtown areas in decline [30]. It was also acknowledged that the policy contributed to urban sustainable development [31]. In Japan, land readjustment is carried out through the implementation of planning and the allocation of land to reduce land fragmentation and improve living conditions [32]. To this end, land holders bring together and plan scattered and irregular agricultural land plots, build roads and infrastructure, and proportionally allocate land after urbanization. Generally speaking, the Western developed countries combine the guidance of government policies with market mechanisms and integrate the use of urban planning, land development permits, public participation, taxes, public capital investment and other policies [33,34].

In China, due to the low degree of land marketization, the expansion of construction land is mainly controlled by the government through command-and-control land use planning, the results of which are not satisfactory [35]. From 2000 to 2010, the total extent of urban construction land expanded from $21,800 \mathrm{~km}^{2}$ to $40,500 \mathrm{~km}^{2}$, an increase of $85 \%$, contrasting sharply with the use control system implemented during this period [36]. Therefore, it has become urgent to reform the land system and establish reasonable policies to control the sprawl of construction land [37]. As a relatively socioeconomically developed city in China, Shenzhen is running out of land [38]. To alleviate tight constraints on land resources, Shenzhen became the first city in China to propose the planning concept of negative growth of construction land [39]: by means of a new land conversion mode, construction land is converted into ecological land to improve the sustainability of land use. This paper attempts to clarify the concepts and practices of construction-to-ecological land conversion (CELC) and summarizes the problems and achievements of CELC in Shenzhen City to provide an example of the regulation and optimization of urban construction land expansion in the process of urbanization.

The remainder of the paper is arranged as follows: (i) a theoretical analysis of the concepts and practices of CELC; (ii) a comparative analysis comparing CELC and other current land conversion models in China and a summary of the characteristics of CELC; and (iii) an introduction to the five areas in which CELC has been carried out in Shenzhen City with an analysis of the opportunities and challenges associated with this approach.

\section{Concepts and Practices of CELC}

CELC is the process of converting construction land into ecological land through land use structure adjustments by government under the guidance of a sustainable land use strategy. Barlowe asserts 
that land use activities should be explained in terms of three dimensions: the potential of natural conditions, economic feasibility and system compatibility [15]. Platt connects the three systems with five lines in a "land use-environment-institution system" feedback loop [40] (Figure 1). Accordingly, the process of CELC is as follows:

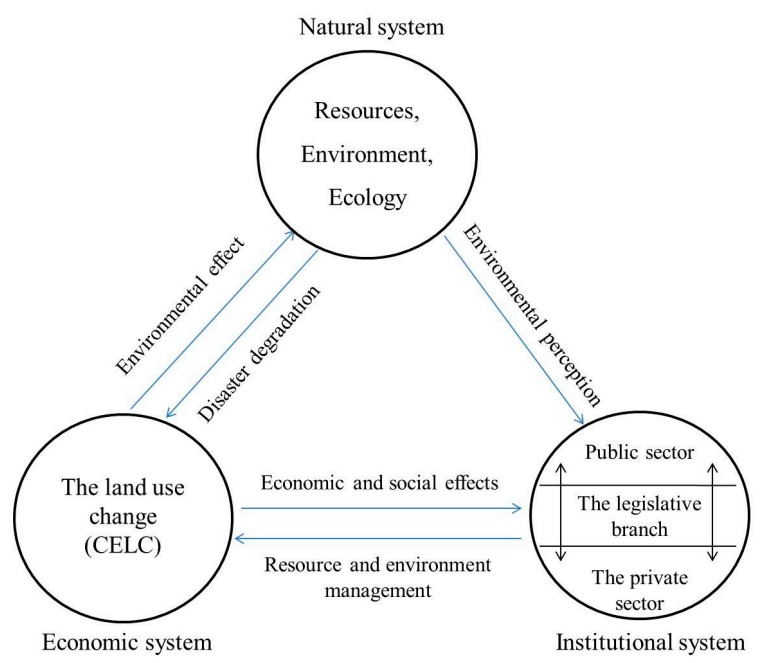

Figure 1. CELC in the "land use-environment—institution system" feedback loop.

\subsection{Land Use}

Land use activities in any form influence the natural environment [41,42]. For example, brownfields have reduced environmental pollution through cleanup and redevelopment [43]. CELC can improve the ecological environment. In addition, the land use system provides information to decision-makers at all levels through economic performance and social effects after CELC, measures of economic feasibility, and social compatibility.

\subsection{Environment}

The natural environment affects land uses, in some cases in extreme ways, such as the disappearance of cultivated land and ecological deterioration, which directly impact the land utilization system. Presently, the improvement of the city's ecological environment indicates the feasibility of CELC. In addition, environmental issues, such as resource exhaustion, environmental deterioration, and ecological damage have aroused the concern of the government and the public.

\subsection{Institutions}

Due to tight constraints on urban land resources, the pattern of construction-driven expansion is unable to continue. The government carries out CELC through laws, regulations, policies, and other means to promote the sustainable use of land resources. From the legislative point of view, people who work directly on the land pay more attention to the economic benefits of land use, and land management departments focus on the social, economic and environmental effects of the land use system at the regional level. The two groups often differ and even conflict [44].

The "land use-environment-institution system" feedback loop shows how the processes at play vary with the social system, with economic development, and with social values in different periods, which is a very complex process.

\section{Comparison of the Types of Land Conversion}

At present, China's land conversion patterns fall into three categories: rural-to-urban land conversion [45], land rehabilitation [46], and urban renewal [47] (Table 1). 
Table 1. Comparison of different types of land conversion.

\begin{tabular}{|c|c|c|c|c|c|}
\hline \multirow{2}{*}{\multicolumn{2}{|c|}{ Types }} & \multicolumn{2}{|c|}{ Land Use } & \multirow{2}{*}{ Environmental Effect } & \multirow{2}{*}{ System Response } \\
\hline & & Before Land Conversion & After Land Conversion & & \\
\hline \multicolumn{2}{|c|}{ Rural-to-urban land conversion } & $\begin{array}{l}\text { Agricultural land } \\
\text { Unused land }\end{array}$ & Construction land & $\begin{array}{l}\text { 1. Land use intensity } \\
\text { 2. Sustainable urban development }\end{array}$ & $\begin{array}{l}\text { 1. Government leadership } \\
\text { 2. Mature system of policies and regulations } \\
\text { 3. Government investment } \\
\text { 4. Science-based standards } \\
\text { 5. Public participation needs improvement }\end{array}$ \\
\hline \multirow{3}{*}{$\begin{array}{l}\text { Land } \\
\text { rehabilitation }\end{array}$} & Land exploitation & $\begin{array}{l}\text { Agricultural land } \\
\text { Unused land }\end{array}$ & Arable land & $\begin{array}{l}\text { 1. Treatment of water and soil erosion } \\
\text { 2. Suitable living environment }\end{array}$ & $\begin{array}{l}\text { 1. Government leadership } \\
\text { 2. Mature system of policies and regulations } \\
\text { 3. Government investment } \\
\text { 4. Science-based standards } \\
\text { 5. Public participation needs improvement }\end{array}$ \\
\hline & Land consolidation & $\begin{array}{l}\text { Agricultural land } \\
\text { Construction land }\end{array}$ & $\begin{array}{l}\text { Agricultural land } \\
\text { Construction land }\end{array}$ & $\begin{array}{l}\text { 1. Improvement of soil nutrients and } \\
\text { production conditions } \\
\text { 2. Suitable living environment }\end{array}$ & $\begin{array}{l}\text { 1. Government leadership } \\
\text { 2. Mature system of policies and regulations } \\
\text { 3. Multiple financing methods } \\
\text { 4. Science-based standards } \\
\text { 5. High degree of public participation }\end{array}$ \\
\hline & Land reclamation & $\begin{array}{l}\text { Destroyed land } \\
\text { Abandoned land }\end{array}$ & Ecological land & $\begin{array}{l}\text { 1. Recovery of the land to a reusable state } \\
\text { 2.Enhancement of soil and water } \\
\text { conservation capacity }\end{array}$ & $\begin{array}{l}\text { 1. Government leadership } \\
\text { 2. Mature system of policies and regulations } \\
\text { 3. Earmarked government funds } \\
\text { 4. Science-based standards } \\
\text { 5. High degree of public participation }\end{array}$ \\
\hline \multirow{3}{*}{ Urban renewal } & $\begin{array}{l}\text { Demolition and } \\
\text { reconstruction }\end{array}$ & $\begin{array}{l}\text { Construction land (old } \\
\text { towns, factories, villages) }\end{array}$ & Construction land & $\begin{array}{l}\text { 1. More sustainable land use } \\
\text { 2. Improvedurban environment }\end{array}$ & \multirow{3}{*}{$\begin{array}{l}\text { 1. Combination of government and market force } \\
\text { 2. Mature system of policies and regulations } \\
\text { 3. Multiple financing methods } \\
\text { 4. Science-based standards } \\
\text { 5. High degree of public participation }\end{array}$} \\
\hline & $\begin{array}{l}\text { Comprehensive } \\
\text { improvement }\end{array}$ & $\begin{array}{c}\text { Construction land } \\
\text { (dilapidated buildings) }\end{array}$ & Construction land & Improved built environment quality & \\
\hline & Overall protection & $\begin{array}{l}\text { Construction land } \\
\text { (historic districts) }\end{array}$ & Construction land & Integrity of architectural style & \\
\hline \multicolumn{2}{|c|}{ Construction-to-ecological land conversion } & Construction land & Ecological land & $\begin{array}{l}\text { 1. More sustainable land use } \\
\text { 2. Improved urban ecosystems }\end{array}$ & $\begin{array}{l}\text { 1. Government leadership } \\
\text { 2. Government investment }\end{array}$ \\
\hline
\end{tabular}




\subsection{Rural-to-Urban Land Conversion}

Rural-to-urban land conversion is a government practice in which the government converts communal land into state-owned land after payment of a land acquisition compensation fee using the land expropriation power and then develops the land in accordance with a construction land planning permit [48]. The essence of rural-to-urban land conversion is the allocation of land resources among different uses led by the government. Chinese land management law stipulates that when building on occupied land, if the conversion of agricultural land into construction land is involved, then the project shall be subject to rural-to-urban land conversion approval procedures. Although the Chinese government implements the construction land approval system, in practice, a large amount of agricultural land is converted into construction land, resulting in a disorderly expansion of construction land [49].

\subsection{Land Rehabilitation}

Land rehabilitation is a comprehensive treatment of land use in the environment and involves three major modes: land exploitation, land consolidation and land reclamation [50]. Land rehabilitation is mainly for agricultural land and unused land, including rural construction land, wastelands, and land degraded by mining. From the perspective of the land use structure after the implementation of land rehabilitation, the proportion of agricultural land to construction land changes. In recent years, land consolidation has achieved good results in practice. In 1999, the Chinese government began to implement the "Grain for Green" program, which relieved the negative effect of the slope cropland on the environment and, thus, effectively prevented soil erosion and desertification [51]. From 2001 to $2009,24,881 \mathrm{~km}^{2}$ of arable land area was added nationwide through land consolidation, accounting for approximately $2 \%$ of the total arable land [52]. WenjuYun, a deputy director and researcher in the Land Consolidation Centre of the Ministry of Land and Resources, noted that the aims of land consolidation are to strengthen the protection of farmland, improve land utilization efficiency, promote resource conservation, and fully realize the ecological functions of the land [53].

\subsection{Urban Renewal Pattern}

Urban renewal is a revival strategy proposed in response to the global industrial chain transfer in old industrial cities in the West, especially in the Great Britain, and the concept was later gradually adopted by the international community [54]. In China, with the continuous advancement of urbanization, urban renewal encompasses a wider range of activities, including demolition and reconstruction, comprehensive improvement, and overall protection [55]. From the perspective of land conversion, comprehensive improvement and overall protection give the land new functions through the transformation of buildings but do not involve the conversion of land use. Demolition and reconstruction involve the adjustment of the urban land use structure, such as the conversion of inefficiently used land to urban public space or urban green space [56]. Urban renewal involves a combination of the government and the market. Since its policy system is rather mature and the public participation level is high, this approach can effectively promote the sustainable use of land.

\subsection{Comparative Analysis}

Compared with the three models described above, CELC differs in land use, environmental effects and system response.

Land use: (i) The three models described above target-specific land types that are quite limited, while CELC covers a wider range of land types, including fragmented land, inefficiently used land, seriously polluted land, and illegally used land; (ii) After conversion, in the three above-described models, the land will be developed accordingly and will continue to be exploited for its productive functions while, after CELC, the land will function mainly as ecological areas, and no more massive development activities will be undertaken on it. 
Environmental effects: (i) The three models above aim to exploit the economic and social value of the land. The land conversion will create comfortable, productive places and living spaces and, thus, promote land use efficiency and profit. However, CELC focuses on the ecological value of the land, which can effectively improve the ecological environment and provide residents with better living spaces; (ii) In the three models, the land layout is optimized to maximize the capacity of the resources and environment and avoid the risks of environmental deterioration. In CELC, the extent of built land is decreased to control sprawl and promote the sustainability of land resources.

System response: (i) After years of exploration and practice, the three above models are mature in terms of their targeted lands, policies and regulations, financial security, technical standards and public participation, while CELC has been put into practice for only a few years, and its enforcement mechanisms are imperfect and need to be improved; (ii) With the support of central government, the three models have been practiced extensively in the country; much experience has been accumulated, many goals have been achieved, and social benefits have been obtained. However, CELC has been implemented on only a small scale, and its social benefits require further evaluation.

\section{Shenzhen Practices and Results}

Situated in the south of Guangdong Province, adjacent to Hong Kong, Shenzhen City is located at $22^{\circ} 27^{\prime}-22^{\circ} 52^{\prime} \mathrm{N}$ and $113^{\circ} 46^{\prime}-114^{\circ} 37^{\prime} \mathrm{E}$, covering an area of $1996 \mathrm{~km}^{2}$ (Figure 2). Since the establishment of the special economic zone, Shenzhen City has experienced rapid urbanization, with an increase of urban construction land from $3 \mathrm{~km}^{2}$ in 1980 to $976 \mathrm{~km}^{2}$ in 2015, nearly $50 \%$ of the city's total area. The rapid expansion of urban construction has exerted great pressure on the ecological environment [57]. Due to the shortage of land, Shenzhen City faces severe challenges to its sustainability [58]. Therefore, in 2009, the Shenzhen municipal government proposed the implementation of CELC to improve the ecological environment and promote the sustainable development of the city by adjusting the land use structure.

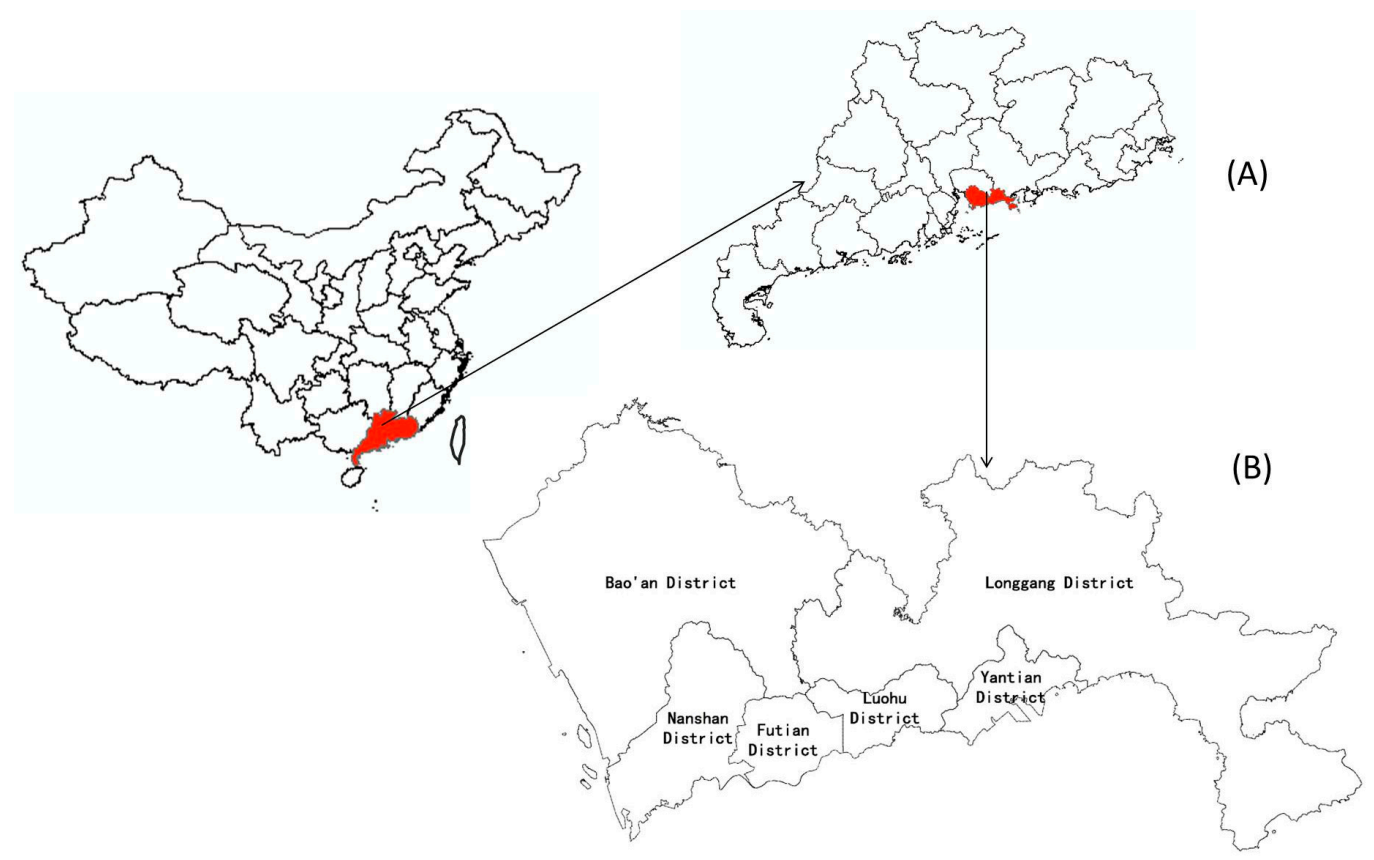

Figure 2. The location of the study area in China: (A) the location of Shenzhen in Guangdong province, China; and (B) Shenzhen administrative area map. 


\subsection{CELC in Basic Farmland Protection Areas}

In 1994, China began to strengthen basic farmland protection. In 1998, the revised land management law clearly stated the implementation of a basic farmland protection system [59]. To realize the goal of basic farmland protection, the central government established overall land use planning objectives and allocated a specific protection area quota to each local government. However, with the acceleration of urbanization, the spatial conflict between urban construction land expansion and the protection of basic farmland continues to deepen [60]. Basic farmland area decreases continually, with a national decrease of $82,660 \mathrm{~km}^{2}$ from 1996 to 2011 in total, a reduction of 6.4\% [61]. In Shenzhen City and other cities in China, considerable basic farmland has been occupied by urban construction. As a result, it has been difficult to complete the task assigned by the state; therefore, the basic farmland protection quota was reduced from $60 \mathrm{~km}^{2}$ in 1997 to $20 \mathrm{~km}^{2}$ in 2009 . Due to reductions in the amount of basic farmland, the function of mass grain production has been lost [62].

In addition, the construction that has occurred on land transformed from basic farmland is dispersed throughout the basic farmland protection area, which seriously pollutes the surrounding area and threatens the ecological security of the city (Figure 3A). From the perspective of land conversion, the common approach worldwide is to vigorously develop ecological agriculture [63]. For example, in 1988, the European Community Committee stipulated that, to control production and ensure environmental protection, a certain proportion of low-yield farmland would be converted to ecological land to protect biological diversity, and compensation would be offered to the farmers who restore natural vegetation [64].

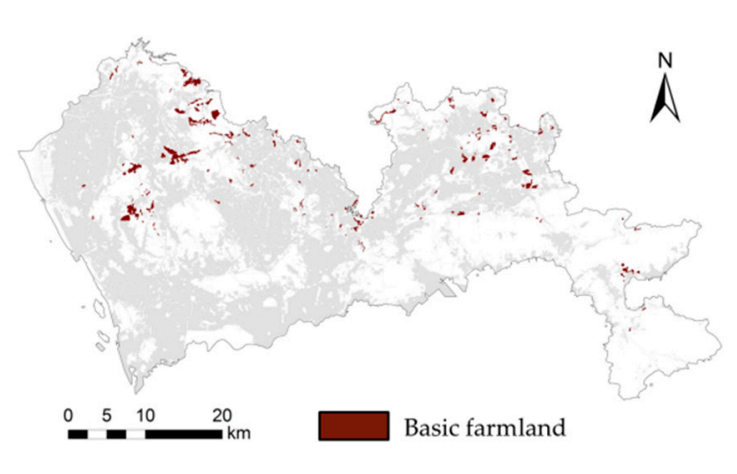

(A)

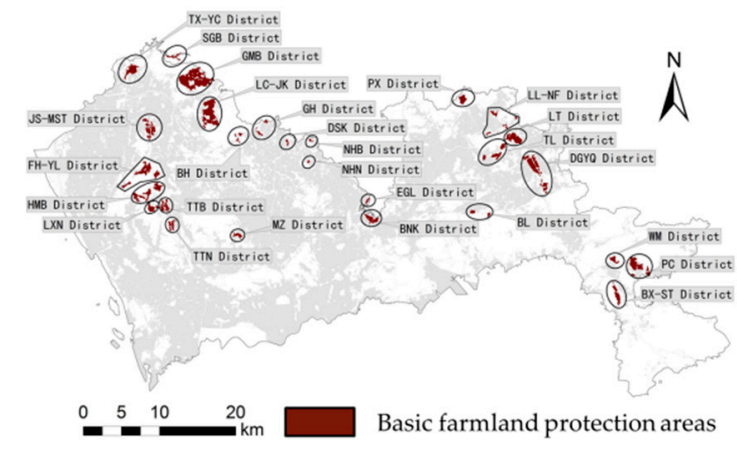

(B)

Figure 3. Basic farmland distribution: (A) basic farmland distribution before adjustment; and (B) 27 basic farmland protection areas.

In view of the serious pollution of the basic farmland and related issues, in 2010, the Shenzhen municipal government designated 27 basic farmland protection areas (Figure 3B) and proposed to optimize their course of action and their measures of land use. The Shenzhen municipal government vigorously promoted the work, developed a detailed land conversion programme and basic farmland transformation plan, and extensively publicized their efforts to solicit opinions, receiving national recognition for their work. From 2011 to 2013, the Shenzhen municipal government invested 1 billion yuan in converting $1.01 \mathrm{~km}^{2}$ of built area into a modern eco-agricultural area. Although China and Western developed countries express their ecological agriculture in different ways, their purposes are the same, that is, to achieve ecological protection and sustainable utilization of land resources [65]. As the American scholar Taylor noted, "China's ecological agriculture is driven by the government to a large extent, and places more emphasis on the theoretical guidance of ecology" [66]. 


\subsection{CELC in Mining Areas}

For thousands of years, the exploitation of mineral resources has brought great wealth to mankind [67]. More than $95 \%$ of China's energy, more than $80 \%$ of industrial raw materials, and more than $70 \%$ of agricultural inputs are from mineral resources. However, mining leads to environmental pollution. Tailings, brownfields, and waste residues endanger ecological security. There are only a few types of mineral resources in Shenzhen City, most of which are quarries that supply stone for urban construction and water vapour minerals for the residents. In 2001, there were 14 quarries and eight water vapour mineral mines being exploited. Mining activities occupy, destroy and pollute a large amount of land and affect the sustainable use of urban land.

Ecologically, the sustainable use of mining land not only involves ecological restoration but must also meet the needs of social and economic development, as well as the combination of natural and cultural interests [68]. International examples exist of lands formerly used for mining being converted into farmland and forests or for tourism and leisure or animal husbandry [69]. For example, the United Kingdom transformed abandoned mines into National Forestlands [70]. Germany initially reclaimed mines into single-purpose green spaces and then further developed them into multipurpose land [71].

Since 2009, the Shenzhen municipal government has gradually closed the abandoned mines (Figure 4B), making use of a special fund for reclamation and mineral resources to supply the necessary compensation. The old mines have been transformed into ecological land with a total area of $3.17 \mathrm{~km}^{2}$ (Figure 4C), which has effectively improved the urban ecological environment. In addition, according to the natural, social, and economic characteristics, the government appropriately accommodates human activities and determines the use of converted land, such as tourism, science, and education, and other uses, to achieve the sustainable utilization of former mining land.

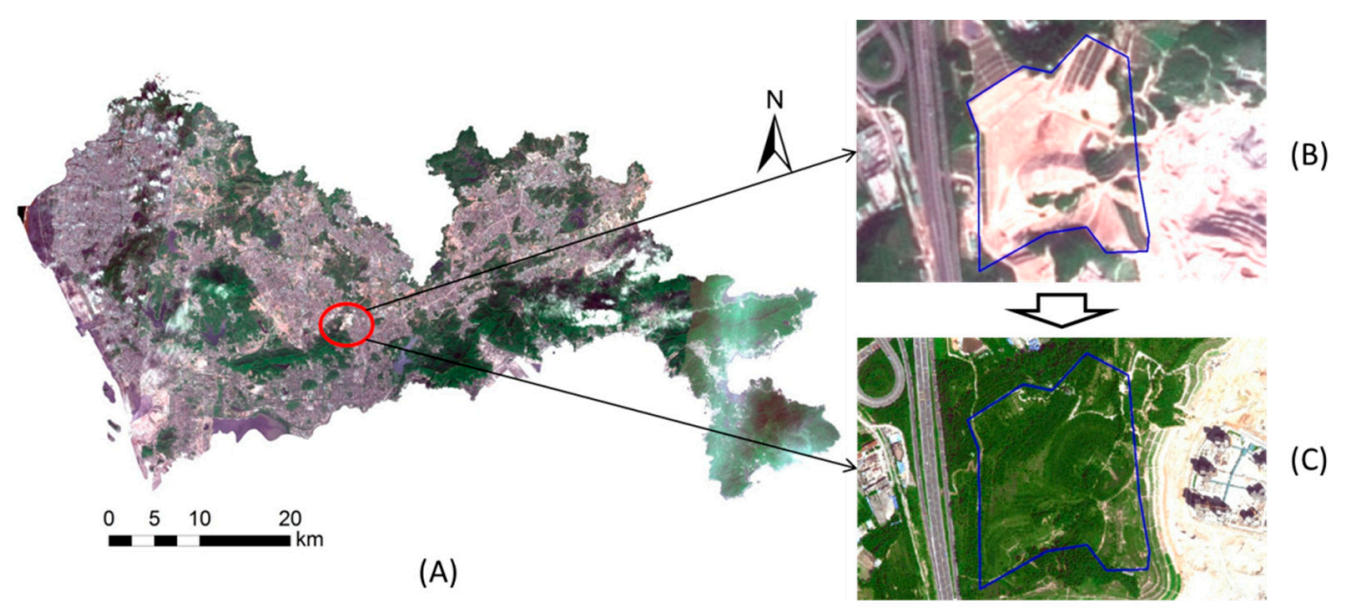

Figure 4. Mining areas before and after CELC: (A) remote sensing image figure; (B) before CELC; and $(\mathbf{C})$ after CELC.

\subsection{CELC in Ecological Corridors}

To control the disorderly expansion of urban built land, the Shenzhen municipal government delineated the urban growth boundary (UGB) in 2005, including primary water source protection areas, scenic areas, nature reserves, forests and parks, mountains, the main rivers, reservoirs, wetlands, ecological corridors, islands, and other features, with a total area of $974 \mathrm{~km}^{2}$ [72]. Additionally, within the UGB, based on mountains, reservoirs, coastline, and other natural areas, an ecological security network of "four zones" and "six corridors" was delineated (Figure 5A). 


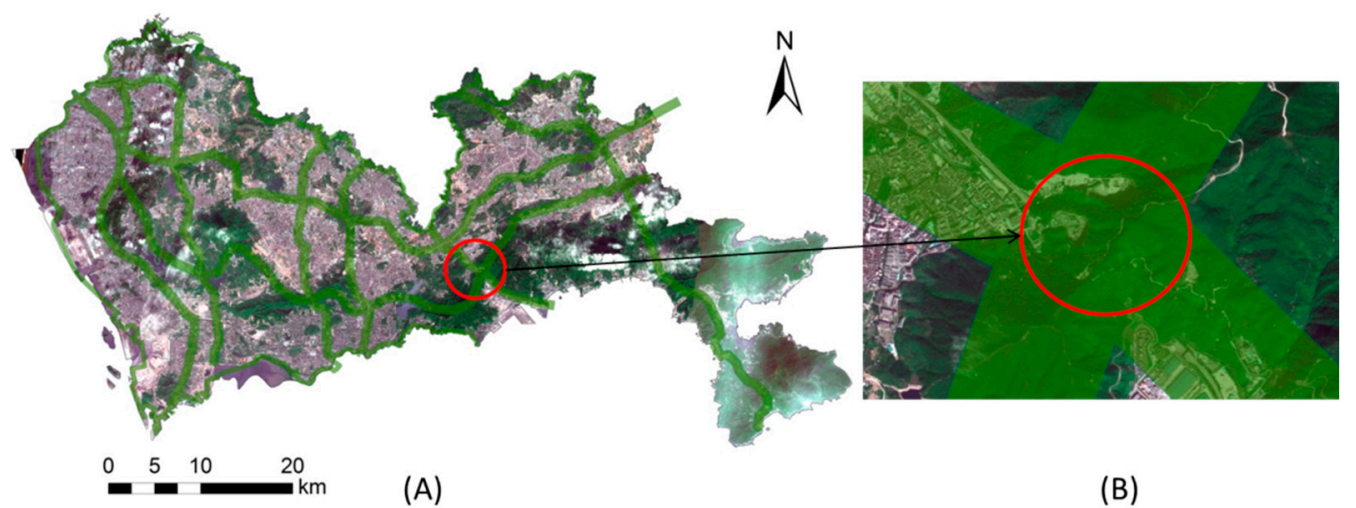

Figure 5. CELC of ecological corridors: (A) distribution of ecological corridors; and (B) a land plot in ecological corridor after CELC.

The "four zones" refer to the four ecological protection zones in the north, central north, central south, and south; the "six corridors" refer to the six ecological corridors of Baoan-Guangming, Baoan-Nanshan, Baoan-Futian, Longgang-Luohu, Longgang-Yantian, and Longgang-Dapeng. Before delineation, both residential land and tourist land were present in this area, which were dispersed and difficult to equip with environmental protection facilities. A geological disaster in this area would pose a serious risk of landscape erosion that could undermine urban ecological security.

Since 2009, the Shenzhen municipal government has restricted development and construction in ecological corridors and cleaned up a $0.52 \mathrm{~km}^{2}$ of brownfield, transforming it into ecological land with a high degree of vegetation coverage. To achieve CELC, the Shenzhen municipal government engaged in policy advocacy, sought public participation and secured funds for ecological compensation. For example, public awareness of the importance of ecological protection was raised by establishing an ecological information disclosure system to produce public service ads, billboards, websites and other forms of policy propaganda; an ecological protection "hotline" was opened, and questionnaire surveys were distributed to fully solicit public opinion; ecological compensation standards were defined, and people were compensated for the economic losses caused by the ecological protection. By means of land conversion, the construction land in the ecological corridors has been transformed into ecological land (Figure 5B). The removal of the previous construction land has thus created an open and free ecological land network, which provides space for the migration and breeding of wild animals and effectively controls urban expansion [73].

\subsection{CELC in Inefficient Industrial Zones}

Shenzhen takes advantage of its location adjacent to Hong Kong and cheap land resources to attract foreign investment to improve the industrialization of its rural areas [74]. The lack of planning guidance for bottom-up development and construction leads to the disorderly expansion of construction land, which occupies a large fraction of the land within the basic ecological control zone. Illegal industrial land located within the basic ecological protection area covers $22 \mathrm{~km}^{2}$, of which inefficient industrial zones occupy $4 \mathrm{~km}^{2}$, accounting for approximately $18 \%$.

The industrial zone is faced with the following problems: (i) There are many heavily-polluting manufacturing industries in the industrial zones, such as metals, plastics, and other industries, which negatively affect urban ecological security; (ii) Without industrial agglomeration, the industrial zones are small, scattered and unable to be upgraded; (iii) Due to complex land property rights, the land market in the industrial zones is disorderly and not conducive to efficient use. For example, the rent for a common industrial plant is approximately $8-10$ yuan per $\mathrm{m}^{2}$, only $15 \%$ of the potential rent for this type of property. 
To promote the sustainable use of land resources, the Shenzhen municipal government undertook the transformation of inefficient industrial land within the ecological control zone into ecological land. In five years, only $0.3 \mathrm{~km}^{2}$ has been converted (Figure 6), mainly because the inefficient industrial zones were built on the initiative of the original rural collectives. After several private deals, the government still struggles to define the rights and interests of all parties when implementing CELC. From the perspective of land conversion, the common approach is to design ecological protection policy on the basis of the clarification of property rights, encouraging the residents to move out of ecological control zones and giving them appropriate economic compensation in return. For example, the Chinese government formulated protection policy in the panda habitats $[75,76]$. In recent years, Shenzhen City has reformed the land management system, allowing the original rural collective industrial land which is in accordance with the planning to come onto the market, the profit of which is divided proportionally between the government and the original villagers [77]. The common practice is to raise the economic compensation to increase the enthusiasm of the original villagers so as to encourage them to participate in the ecological protection. The implementation of this policy will make the introduction of CELC to the market possible.

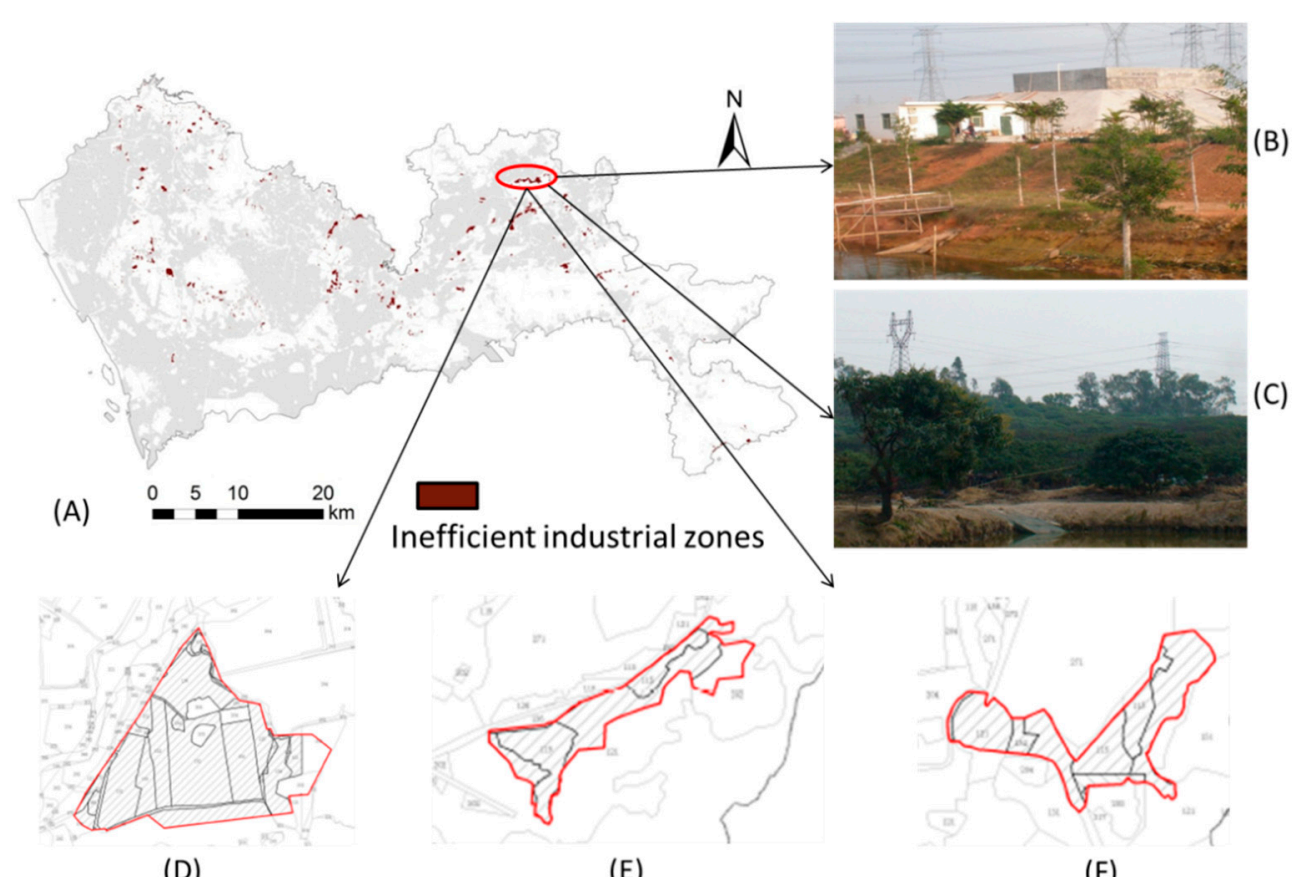

(D)

$(\mathrm{E})$

$(\mathrm{F})$

Figure 6. Figures of inefficient industrial land before and after CELC: (A) distribution of inefficient industrial land; (B) before CELC; (C) after CELC; (D-F): land plots.

\subsection{Village Construction Land Conversion}

Shenzhen City has experienced two urban land conversions, in 1992 and 2004, in which all of the land became state owned, but due to incomplete land transfer, a large number of urban villages in the city arose [78]. There were a total of 2230 village communities in the city in 2010, covering an area of $106 \mathrm{~km}^{2}$. In these villages, the original villagers rushed to build a large number of illegal structures and domiciles. By 2014, a total of 373,000 illegal buildings had been built in Shenzhen City, with a total footprint of 428 million $\mathrm{m}^{2}$, accounting for $43 \%$ of the total construction area [79].

The rental of private houses increases the original villagers' income, and these houses provide living places for a large number of workers and ease the social contradictions; therefore, the illegal construction in the urban villages is allowed in practice. The problems in the urban villages are mainly as follows: (i) urban villages occupy considerable land resources, restricting the sustainable utilization of urban land; (ii) the unplanned municipal infrastructure and lack of public facilities in urban 
villages have brought inconvenience to the lives of residents; (iii) the disorderly construction layout and absence of green landscapes in urban villages have harmed the urban ecological environment; and (iv) the housing planning and construction in urban villages is old and of a low standard, which now poses widespread security risks.

In recent years, the Shenzhen municipal government has implemented urban renewal and land remediation measures, among which the "overall planning of the whole village" is considered an effective means [80]. For example, from 2010 to 2013, Shenzhen invested 3.8 billion yuan in the Jinsha, $\mathrm{Nanbu}$, and Shahu communities to test this approach (Figure 7). These land conversion measures resulted in the conversion of $1.5 \mathrm{~km}^{2}$ of illegally-used land into ecological land, effectively improving the ecological environment of the communities; communities acquired $1.42 \mathrm{~km}^{2}$ for development and attempted a transformation from a single-plant rental economy to a diversified economy to achieve an organic combination of community development and urban development. The government had access to an area of $2.96 \mathrm{~km}^{2}$ for development, most of which was for municipal facilities and public service facilities.

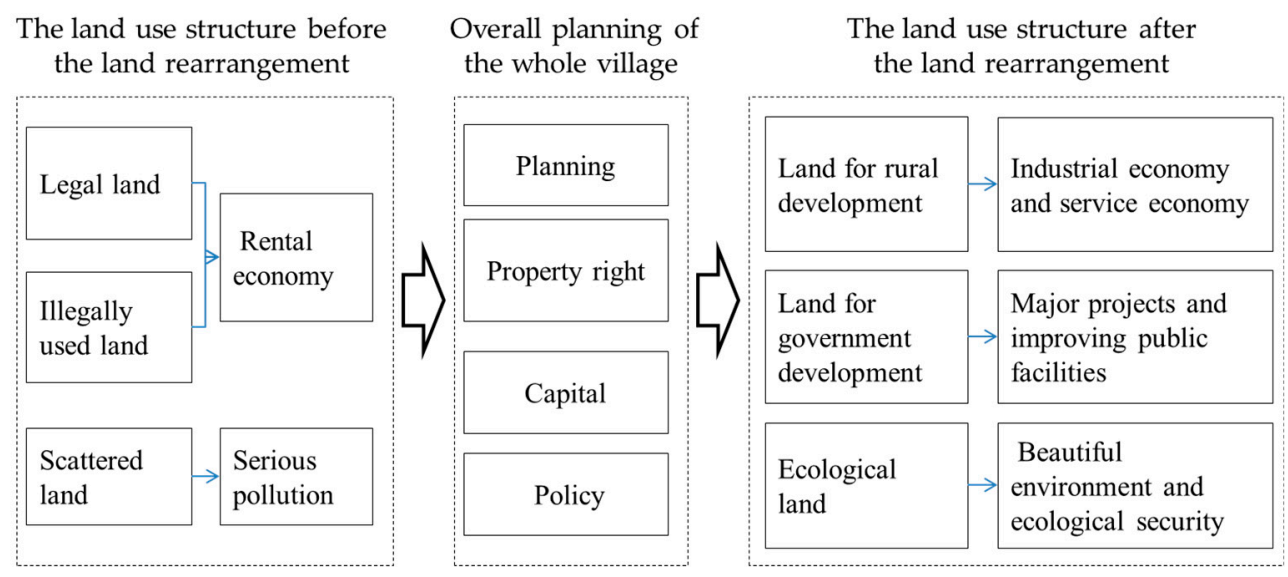

Figure 7. The land use conversion in the overall planning of the whole village.

\section{Conclusions and Discussion}

Shenzhen City, to some extent, has effectively improved its ecological environment, and promoted the sustainable use of land resources by applying CELC in five areas. However, in practice, CELC still faces enormous legal, financial, technological, and political challenges.

First, the land use aspects of CELC focus on the ecological functions of the land. Since it can provide the city with good ecological space, CELC has won the support of the public and environmentalists and achieved beneficial social effects. However, as a new land transfer approach, CELC has been implemented for only a few years, and many aspects of this approach are not mature. It takes considerable capital and time to complete land conversion in any area of CELC. Moreover, as noted above, the central government controls local development and construction through quota distribution. To avoid excessively tight control over local government, the central government has acquiesced to local governments fulfilling their preservation quotas with land converted by CELC [81]. CELC provides the local government with abundant land for use. However, it is worthwhile to consider how the local government can avoid abusing the allocation of this new land and ensure the prevention of urban sprawl.

Second, considering the environmental effects, there must be a system of criteria used to measure whether a damaged ecosystem has been successfully restored [82]. Although Berger [83], Krabbenhoft [84], and others have established a set of evaluation systems to assess the ecological restoration of damaged ecosystems, no universal evaluation system is yet available [85]. Due to the significant differences in environmental conditions and imperfect evaluation systems, it is difficult 
to make an accurate assessment of the success of environmental recovery when construction land is converted into ecological land. In addition, some practices may lead to new environmental damage or secondary pollution. As the ecological restoration expert Bradshaw noted, for restoration to be successful, new environmental problems must be solved; otherwise, it is unlikely to succeed [86].

Third, considering institutional systems, the legitimacy of CELC is questioned. The Chinese Constitution stipulates that "the state may, in the interest of the public, expropriate or requisition the private property of citizens in accordance with the law and give compensation". Although the Shenzhen municipal government uses the public interest as a rationale to implement CELC and give appropriate compensation, whether CELC in fact conforms to the public interest is not clearly defined. Institutional economics holds the view that the interests of the system and the public interests are the same, yet the government, as an interest group, often has interests that conflict with those of the public [87]. The problem of how to define the public service nature of CELC through open and democratic procedures so that the administrative subject and public rights can be balanced in a real sense is unavoidable.

Rapid urban development in China over the past 30 years has put great pressure on urban ecological systems and underscored the need for environmental protection [88]. CELC is a land conversion type advanced by Shenzhen City to adapt the national land quota system to its own reality. CELC is related to land use control, land development rights and public participation. To some extent, the implementation of CELC can effectively improve the ecological environment and promote sustainable land use. In 2014, the central government put forward a new urbanization strategy emphasizing people-oriented and sustainable development [89], and the experience and practice of Shenzhen provides a model for other cities to explore sustainable land use.

Acknowledgments: This study was supported by the National Natural Science Foundation of China (Project No. 41571438 and 41371427) and Hubei Key Laboratory of Regional development and environmental response (Hubei University, 2015-B-002).

Author Contributions: Yunfei Peng, Jing Qian, Fu Ren, Wenhui Zhang and Qingyun Du worked collectively. Specifically, Yunfei Peng conceived and designed the study with the support of Qingyun Du. Fu Ren gave constructive suggestions for the idea and the writing. All the co-authors drafted and revised the article together. All authors read and approved the final manuscript.

Conflicts of Interest: The authors declare no conflict of interest.

\section{References}

1. Qian, J.; Peng, Y.; Luo, C.; Wu, C.; Du, Q. Urban land expansion and sustainable land use policy in Shenzhen: A case study of China's rapid urbanization. Sustainability 2016, 8, 16. [CrossRef]

2. Verburg, P.H.; Chen, Y.; Veldkamp, T. Spatial explorations of land use change and grain production in China. Agric. Ecosyst. Environ. 2000, 82, 333-354. [CrossRef]

3. Bao, H.; Peng, Y. Effect of land expropriation on land-lost farmers' entrepreneurial action: A case study of Zhejiang province. Habitat Int. 2016, 53, 342-349. [CrossRef]

4. Xiao, J.; Shen, Y.; Ge, J.; Tateishi, R.; Tang, C.; Liang, Y.; Huang, Z. Evaluating urban expansion and land use change in Shijiazhuang, China, by using GIS and remote sensing. Landsc. Urban Plan. 2006, 75, 69-80. [CrossRef]

5. Stone, B. Urban sprawl and air quality in large US cities. J. Environ. Manag. 2008, 86, 688-698. [CrossRef] [PubMed]

6. Aronson, M.F.J.; La Sorte, F.A.; Nilon, C.H.; Katti, M.; Goddard, M.A.; Lepczyk, C.A.; Warren, P.S.; Williams, N.S.G.; Cilliers, S.; Clarkson, B.; et al. A global analysis of the impacts of urbanization on bird and plant diversity reveals key anthropogenic drivers. Proc. R. Soc. B 2014, 281, 20133330. [CrossRef] [PubMed]

7. The National New Urbanization Report 2015. Available online: http://www.gov.cn/xinwen/2016-04/19/ content_5065930.htm (accessed on 19 April 2016).

8. Huang, Z.; Wei, Y.D.; He, C.; Li, H. Urban land expansion under economic transition in China: A multi-level modeling analysis. Habitat Int. 2015, 47, 69-82. [CrossRef] 
9. Feng, J.; Lichtenberg, E.; Ding, C. Balancing act: Economic incentives, administrative restrictions, and urban land expansion in China. China Econ. Rev. 2015, 36, 184-197. [CrossRef]

10. Halleux, J.; Marcinczak, S.; van der Krabben, E. The adaptive efficiency of land use planning measured by the control of urban sprawl. The cases of the Netherlands, Belgium and Poland. Land Use Policy 2012, 29, 887-898. [CrossRef]

11. Li, H.; Wei, Y.; Huang, Z. Urban land expansion and spatial dynamics in globalizing Shanghai. Sustainability 2014, 6, 8856-8875. [CrossRef]

12. Jackson, K. The Suburbanization of the United States; Oxford University Press: New York, NY, USA, 1985.

13. Peterson, G. The Influence of Zoning Regulations on Land and Housing Prices; The Urban Institute: Washington, DC, USA, 1974.

14. Dipasquale, D.; Wheaton, W. Urban Economics and Real Estate Markets; Prentice Hall: Englewood Cliffs, NJ, USA, 1996.

15. Barlowe, R. Land Resource Economics: The Economics of Real Estate; Prentice-Hall: Englewood Cliffs, NJ, USA, 1978.

16. Nelson, A.C.; Moore, T. Assessing growth management policy implementation: Case study of the United States' leading growth management state. Land Use Policy 1996, 13, 241-259. [CrossRef]

17. Daniels, T. Smart growth: A new American approach to regional planning. Plan. Pract. Res. 2001, 16, $271-279$. [CrossRef]

18. Garrett, R.D.; Lambin, E.F.; Naylor, R.L. The new economic geography of land use change: Supply chain configurations and land use in the Brazilian Amazon. Land Use Policy 2013, 34, 265-275. [CrossRef]

19. Jongman, R.; Pungetti, G. Ecological Networks and Greenways: Concept, Design, Implementation; Cambridge University Press: Cambridge, UK, 2004.

20. Cohen, S.E. Greenbelts in London and Jerusalem. Geogr. Rev. 1994, 84, 73-89. [CrossRef]

21. Wu, Z.; Feng, C.; Yang, Z. The theory of land use in the development of compact cities. Urban Probl. 2012, 1, 9-14. (In Chinese)

22. Hayashi, K. Land readjustment in Nagoya. In Land Readjustment: A Different Approach to Financing Urbanization; Doebele, W., Ed.; Lexington Books: Lexington, KY, USA, 1982.

23. Delmelle, E.; Zhou, Y.; Thill, J. Densification without growth management? Evidence from local land development and housing trends in Charlotte, North Carolina, USA. Sustainability 2014, 6, 3975-3990. [CrossRef]

24. Handy, S. Smart growth and the transportation-land use connection: What does the research tell us? Int. Reg. Sci. Rev. 2005, 28, 146-167. [CrossRef]

25. Hirschhorn, J.; Souza, P. New Community Design to the Rescue: Fulfilling Another American Dream; National Governors Association: Washington, DC, USA, 2001.

26. Walmsley, A. Greenways: Multiplying and diversifying in the 21st century. Landsc. Urban Plan. 2006, 76, 252-290. [CrossRef]

27. Amati, M.; Yokohari, M. Temporal changes and local variations in the functions of London's green belt. Landsc. Urban Plan. 2006, 75, 125-142. [CrossRef]

28. Needham, B.; Dekker, A. The fourth report on physical planning in the Netherlands. Neth. J. Hous. Environ. Res. 1988, 3, 335-344. [CrossRef]

29. Nicole, M. The compact city: Theory versus practice-the case of Cambridge. Neth. J. Hous. Built Environ. 1998, 13, 157-179.

30. Department of Infrastructure. Melbourne 2030_Planning for Sustainable Growth; Department of Infrastructure: Victoria, Australia, 2002.

31. Burgess, R.; Jenks, M. Compact Cities: Sustainable Urban Forms for Developing Countries; Routledge: New York, NY, USA, 2002.

32. Misra, B. Japanese experience in physical development and land management. In Transferability of Development Experience (Regional Development Dialogue, Special Issue 1984); Okita, S., Ed.; United Nations Centre for Regional Development: Nagoya, Japan, 1984.

33. De Baan, L.; Alkemade, R.; Koellner, T. Land use impacts on biodiversity in LCA: A global approach. Int. J. Life Cycle Assess. 2013, 18, 1216-1230. [CrossRef]

34. Couch, C.; Fraser, C.; Percy, S. Urban Regeneration in Europe; John Wiley \& Sons: New York, NY, USA, 2008. 
35. Lv, X.; Huang, X. Research progress and prospect of construction land expansion. Geogr. Geoinfor. Sci. 2013, 6,51-58. (In Chinese)

36. Qu, Y.; Sun, S.; Chen, Y. The expansion and strategy of controlling china's urban construction land. Resour. Sci. 2014, 1, 1-7. (In Chinese)

37. Cottyn, H.; Vanhaute, E. The Great Commodification and Its Paradoxes. A Historical, Comparative and Global Perspective on Land Regimes and Land Reforms. An International Colloquium; International Institute of Social Studies: The Hague, The Netherlands, 2016.

38. Luo, G. Unconfirmed Land Policy Change in Shenzhen; Haitian Press: Shenzhen, China, 2014. (In Chinese)

39. Shenzhen City Planning and Land Resources. The Comprehensive Planning of Shenzhen City (2010-2020). Available online: http:/ /www.szpl.gov.cn/ (accessed on 29 September 2010).

40. Platt, R.H. Land Use and Society: Geography, Law, and Public Policy; Island Press: Washington, DC, USA, 1996.

41. Wu, J. Urban ecology and sustainability: The state-of-the-science and future directions. Landsc. Urban Plan. 2014, 125, 209-221. [CrossRef]

42. Li, X. Explanation of land use changes. Prog. Geogr. 2002, 21, 195-202. (In Chinese)

43. Lee, S.; Mohai, P. The socioeconomic dimensions of brownfield cleanup in the Detroit region. Popul. Environ. 2013, 34, 420-429. [CrossRef]

44. Hui, E.C.M.; Bao, H. The logic behind conflicts in land acquisitions in contemporary China: A framework based upon game theory. Land Use Policy 2013, 30, 373-380. [CrossRef]

45. Long, H. Land use policy in China: Introduction. Land Use Policy 2014, 40, 1-5. [CrossRef]

46. Zhang, J.; Pham, T.; Kalacska, M.; Turner, S. Using landsat thematic mapper records to map land cover change and the impacts of reforestation programmes in the borderlands of southeast Yunnan, China: 1990-2010. Int. J. Appl. Earth Obs. Geoinform. 2014, 31, 25-36. [CrossRef]

47. Peng, C.; Ming, T.; Gui, J.; Tao, Y.; Peng, Z. Numerical analysis on the thermal environment of an old city district during urban renewal. Energy Build. 2015, 89, 18-31. [CrossRef]

48. Song, Y.; Wang, M.Y.; Lei, X. Following the money: Corruption, conflict, and the winners and losers of suburban land acquisition in China. Geogr. Res. 2016, 54, 86-102. [CrossRef]

49. Chen, J.; Gao, J.; Chen, W. Urban land expansion and the transitional mechanisms in Nanjing, China. Habitat Int. 2016, 53, 274-283. [CrossRef]

50. Yan, J.; Xia, F.; Bao, H.X.H. Strategic planning framework for land consolidation in China: A top-level design based on SWOT analysis. Habitat Int. 2015, 48, 46-54. [CrossRef]

51. Wang, Z.J.; Jiao, J.Y.; Rayburg, S.; Wang, Q.L.; Su, Y. Soil erosion resistance of “Grain for Green” vegetation types under extreme rainfall conditions on the Loess Plateau, China. CATENA 2016, 141, 109-116. [CrossRef]

52. Wu, C.; Fei, L.; Ye, Y. The theoretical perspective, rational paradigm and strategic solution of land consolidation. Econ. Geogr. 2011, 31, 1718-1722. (In Chinese)

53. Yun, W. Progress and innovation in the theory and practice of land consolidation and rehabilitation in China. Shanghai Land Resour. 2012, 33, 1-6.

54. Mccrone, G. Urban renewal: The Scottish experience. Urban Stud. 1991, 28, 919-938. [CrossRef]

55. Shen, L.; Yuan, H.; Kong, X. Paradoxical phenomenon in urban renewal practices: Promotion of sustainable construction versus buildings' short lifespan. Int. J. Strateg. Prop. Manag. 2013, 17, 377-389. [CrossRef]

56. Lin, G.C.S. The redevelopment of China's construction land: Practising land property rights in cities through renewals. China Q. 2015, 224, 865-887. [CrossRef]

57. Hassan, A.M.; Lee, H. Toward the sustainable development of urban areas: An overview of global trends in trials and policies. Land Use Policy 2015, 48, 199-212. [CrossRef]

58. Futian Government Online. The Government Work Report 2005. Available online: http:/ / www.southen. com/news/dishi/shenzhen/ggl/200506060358.htm (accessed on 6 June 2005).

59. Liu, Y.; Fang, F.; Li, Y. Key issues of land use in China and implications for policy making. Land Use Policy 2014, 40, 6-12. [CrossRef]

60. Wang, H.; Tao, R.; Wang, L.; Su, F. Farmland preservation and land development rights trading in Zhejiang, China. Habitat Int. 2010, 34, 454-463. [CrossRef]

61. Long, H. Land use transition and land management. Geogr. Res. 2015, 34, 1607-1618. (In Chinese)

62. Lichtenberg, E.; Ding, C. Assessing farmland protection policy in China. Land Use Policy 2008, 25, 59-68. [CrossRef] 
63. Li, Y.; Li, Y.; Westlund, H.; Liu, Y. Urban-rural transformation in relation to cultivated land conversion in china: Implications for optimizing land use and balanced regional development. Land Use Policy 2015, 47, 218-224. [CrossRef]

64. Dinter, A.; Oberwalder, C.; Kabouw, P.; Coulson, M.; Ernst, G.; Leicher, T.; Miles, M.; Weyman, G.; Klein, O. Occurrence and distribution of earthworms in agricultural landscapes across Europe with regard to testing for responses to plant protection products. J. Soils Sedim. 2013, 13, 278-293. [CrossRef]

65. Shi, T. Moving towards sustainable development: Rhetoric, policy and reality of ecological agriculture in China. Int. J. Sustain. Dev. World Ecol. 2003, 10, 195-210. [CrossRef]

66. Cheng, X.; Han, C.; Taylor, D.C. Sustainable agricultural development in China. World Dev. 1992, 20, $1127-1144$.

67. Toomik, A.; Liblik, V. Oil shale mining and processing impact on landscapes in north-east Estonia. Landsc. Urban Plan. 1998, 41, 285-292. [CrossRef]

68. Sklenička, P.; Lhota, T. Landscape heterogeneity: A quantitative criterion for landscape reconstruction. Landsc. Urban Plan. 2002, 58, 147-156. [CrossRef]

69. Liu, H. Ecological restoration and sustainable landscape design of mining wastelands. Acta Ecol. Sin. 2004, 24, 323-329. (In Chinese)

70. Cloke, P.; Milbourne, P.; Thomas, C. From wasteland to wonderland: Opencast mining, regeneration and the English national forest. Geoforum 1996, 27, 159-174. [CrossRef]

71. Liang, L.; Chang, J.; Wu, C. Study on the ecological restoration of landscape in Germany mining regions and reference to china. Econ. Geogr. 2002, 22, 711-715.

72. Li, X.; Lao, C.; Liu, Y.; Liu, X.; Chen, Y.; Li, S.; Ai, B.; He, Z. Early warning of illegal development for protected areas by integrating cellular automata with neural networks. J. Environ. Manag. 2013, 130, 106-116. [CrossRef] [PubMed]

73. Yang, T.; Jing, D.; Wang, S. Applying and exploring a new modeling approach of functional connectivity regarding ecological network: A case study on the dynamic lines of space syntax. Ecol. Model. 2015, 318, 126-317. [CrossRef]

74. Chen, J.; Chang, K.; Karacsonyi, D.; Zhang, X. Comparing urban land expansion and its driving factors in Shenzhen and Dongguan, China. Habitat Int. 2014, 43, 61-71. [CrossRef]

75. Liu, J.G.; Vina, A. Pandas, plants, and people. Ann. Mo. Bot. Gard. 2014, 100, 108-125. [CrossRef]

76. Li, Y.; Vina, A.; Yang, W.; Chen, X.D.; Zhang, J.D.; Ouyang, Z.Y.; Liang, Z.; Liu, J.G. Effects of conservation policies on forest cover change in giant panda habitat regions, China. Land Use Policy 2013, 33, 42-53. [CrossRef] [PubMed]

77. Zou, Y.; Zhao, W.; Mason, R. Marketization of collective-owned rural land: A breakthrough in Shenzhen, China. Sustainability 2014, 6, 9114-9123. [CrossRef]

78. Lai, Y.; Peng, Y.; Li, B.; Lin, Y. Industrial land development in urban villages in China: A property rights perspective. Habitat Int. 2014, 41, 185-194. [CrossRef]

79. Qiao, S. Small property, big market: A focal point explanation. Am. J. Comp. Law 2015, 63, 197-237. [CrossRef]

80. Yue, J.; Dai, X.; Lai, W. Interaction between planning and land policies in land rearrangement in the action of "overall planning of whole village": A case study on Shenzhen. City Plan. Rev. 2015, 39, 70-75. (In Chinese)

81. Zhang, W.; Wang, W.; Li, X.; Ye, F. Economic development and farmland protection: An assessment of rewarded land conversion quotas trading in Zhejiang, China. Land Use Policy 2014, 38, 467-476. [CrossRef]

82. Dobson, A.P.; Bradshaw, A.; Baker, A. Hopes for the future: Restoration ecology and conservation biology. Science 1997, 277, 515-522. [CrossRef]

83. Berger, J. A generic framework for evaluating complex restoration and conservation projects. Environ. Prof. 1991, 13, 254-262.

84. Krabbenhoft, K.; Kirby, D.; Biondini, M.; Halvorson, G.; Nilson, D. Topoedaphic unit analysis: A site classification system for reclaimed mined lands. CATENA 1993, 20, 289-301. [CrossRef]

85. Palmer, M.A.; Ambrose, R.F.; Poff, N.L. Ecological theory and community restoration ecology. Rest. Ecol. 1997, 5, 291-300. [CrossRef]

86. Bradshaw, A.D.; Hüttl, R.F. Future minesite restoration involves a broader approach. Ecol. Eng. 2001, 17, 87-90. [CrossRef] 
87. Baland, J.; Platteau, J. Division of the commons: A partial assessment of the new institutional economics of land rights. Am. J. Agric. Econ. 1998, 80, 644-650. [CrossRef]

88. Zhou, H.; Shi, P.; Wang, J.; Yu, D.; Gao, L. Rapid urbanization and implications for river ecological services restoration: Case study in Shenzhen, China. J. Urban Plan. Dev. 2011, 137, 121-132. [CrossRef]

89. Li, W. Failure by design-National mandates and agent control of local land use in China. Land Use Policy 2016, 52, 518-526. [CrossRef]

(C) 2016 by the authors; licensee MDPI, Basel, Switzerland. This article is an open access article distributed under the terms and conditions of the Creative Commons Attribution (CC-BY) license (http://creativecommons.org/licenses/by/4.0/). 